\title{
PENGEMBANGAN BAHAN AJAR ELEKTRONIK BERMUATAN MULTIMEDIA PADA TEMA PEDULI TERHADAP MAKHLUK HIDUP UNTUK SISWA SEKOLAH DASAR KELAS IV DI KABUPATEN NGADA
}

\author{
Imelda Uma Riwu \\ STKIP Citra Bakti Ngada, Nusa Tenggara Timur \\ ilda.riwu94@gmail.com \\ Dek Ngurah Laba Laksana \\ STKIP Citra Bakti Ngada, Nusa Tenggara Timur \\ laba.laksana@citrabakti.ac.id \\ Konstantinus Dua Dhiu \\ STKIP Citra Bakti Ngada, Nusa Tenggara Timur \\ duakonstantinus@gmail.com
}

\begin{abstract}
Abstrak
Penelitian ini bertujuan untuk : (1) menghasilkan bahan ajar elektronik bermuatan multimedia pada tema peduli terhadap makhluk hidup yang sesuai dengan karakteristik siswa sekolah dasar pada siswa kelas iv di kabupaten ngada, (2) mengetahui kualitas hasil uji produk pengembangan bahan ajar elektronik bermuatan multimedia pada tema peduli terhadap makhluk hidup untuk siswa sekolah dasar kelas IV di Kabupaten Ngada. Penelitian ini dilakukan di Kabupaten Ngada Provinsi Nusa Tenggara Timur. Subjek dalam penelitian ini adalah kurikulum 2013 kelas IV dan siswa SD kelas IV di Kabupaten Ngada. Sedangkan objek yang diteliti adalah konten dan konteks kearifan lokal masyarakat Ngada yang relevan diintegrasikan dalam tema peduli terhadap makhluk hidup kelas IV untuk dijadikan sebuah bahan ajar elektronik bermuatan multimedia. Bahan ajar elektronik bermuatan multimedia ini dikembangkan dengan model ADDIE. Model ini terdiri atas lima langkah, yaitu: (1) analyze, (2) design, (3) development, (4) implementation, dan (5) evaluation. Hasil penelitian pengembangan bahan ajar elektronik bermuatan multimedia berdasarkan hasil uji coba ahli dan siswa sebagai pengguna produk adalah sebagai berikut. (1) Uji coba ahli konten/isi ada pada kategori sangat baik, skor tertinggi ada pada aspek pemilihan bahasa, penggunaan kalimat, kesesuaian contoh dan kasus, kesesuaian soal-soal latihan dan kesesuaian isi materi dengan perkembangan TIK, (2) Uji coba ahli desain pembelajaran ada pada kategori sangat baik, skor tertinggi ada pada aspek kemenarikan desain cover dan kejelasan tulisan, (3) Uji coba ahli multimedia ada pada kategori baik, skor tertinggi ada pada aspek gambar/ilustrasi, (4) Uji coba siswa sebagai pengguna produk ada pada kategori sangat baik, skor tertinggi ada pada aspek video mendukung pemahaman materi. Dengan demikian, pengembangan bahan ajar elektronik bermuatan multimedia ini layak digunakan pada siswa sekolah dasar kelas IV.
\end{abstract}

Kata Kunci: Bahan ajar elektronik, Multimedia, Tematik

\begin{abstract}
This present study aims at: (1) developing an electronic based instructional multimedia on cares to living things theme with character based education for fourth graders in Ngada regency, (2) investigating the quality of the final aforementioned product. This study is conducted in Ngada regency, East Nusa Tenggara province. There are two subjects in this study, namely K13 curriculum for fourth graders and four grade students in Ngada regency. Meanwhile, the object of the study is the content and local genius found in Ngada's people which is relevant to be integrated in the product. This product is developed through ADDIE model. This model covers five main stages, they are: (1) analyse, (2) design, (3) development, (4) implementation, and (5) evaluation. The development of the product relies on the expert judgement and field try out to students as the user of the product. These result in (1) the content is categorised as very good, the highest score lies on the aspect of language use, sentence creation, the relevance between a case and example, the suitability of the exercise and its content to the rapid progress of information and technology, (2) the judgement from the expert of instructional design is classified as very good, the highest score lies on the attractiveness of the cover and clarity of the picture, (3) the judgement from expert in multimedia is classified as good, the highest score lies on the illustration aspect, (4) the field try out to students is categorised as very good, the highest score is located on the video that supports learning. In conclusion, the developed electronic based instructional multimedia is applicable for fourth graders.
\end{abstract}

Keywords: electronic based materials, multimedia, thematic

\section{Pendahuluan}

Tujuan pendidikan nasional yang terdapat dalam Undang-undang tentang Sistem Pendidikan Nasional, pemerintah berupaya untuk mencerdaskan kehidupan bangsa dan mengembangkan manusia Indonesia yang seutuhnya, yaitu manusia yang beriman dan bertakwa terhadap Tuhan Yang Maha Esa, berbudi luhur, memiliki pengetahuan dan keterampilan, kesehatan jasmani dan rohani, kepribadian yang mantap dan mandiri, serta rasa tanggung jawab kemasyarakatan dan kebangsaan (Kemendikbud, 2013). 
Dalam standar isi dalam Undang-undang Sisdiknas Nomor 20 Tahun 2003 mengisyaratkan dalam proses pembelajaran, guru harus menyusun bahan ajar yang kontekstual sesuai dengan kebutuhan dan lingkungan masyarakat setempat (Depdiknas, 2003). Sekolah sudah menerapkan lima hari sekolah di mana dalam sehari dilakukan pembelajaran penuh atau full day school (Laksana dan Riwu, 2018). Tingkat kejenuhan siswa akan muncul maka guru harus menciptakan inovasi dalam proses pembelajaran dengan menciptakan suasana belajar yang menyenangkan dan menyusun bahan ajar yang menarik serta kreatif yang dapat menarik perhatian siswa dalam belajar. Kenyataannya masih banyak guru yang menggunakan bahan ajar yang sudah jadi seperti buku tematik yang telah disediakan oleh pemerintah atau LKS yang merupakan hasil dari suatu penerbit yang mungkin tidak sesuai dengan lingkungan di mana siswa tersebut belajar. Hal ini tentunya dapat mempersulit siswa dalam memahami materi yang seharusnya mereka kuasai. Bahan ajar cetak kurang mengedepankan unsur lingkungan dan budaya lokal masyarakat setempat. Sehingga guru sebagai pendidik yang profesional harus menyiapkan bahan ajar yang memperhatikan kondisi lingkungan dan budaya masyarakat setempat (Laksana dan Widiastika, 2017).

Selain itu, penggunaan bahan ajar jadi ini tidak mengedepankan unsur budaya lokal. Padahal unsur ini sangat penting untuk dimasukkan ke dalam proses pembelajaran melalui penyusunan bahan ajar yang memiliki konten budaya lokal. Untuk itu perlu dilakukan upaya pengembangan bahan ajar yang mengutamakan unsur kearifan lokal khususnya budaya lokal masyarakat Ngada yang memiliki ragam budaya yang sangat cocok dimasukkan dalam pembelajaran di Sekolah Dasar (Laksana dan Widiastika, 2017).

Mulyasa (2015) mengatakan bahwa dalam pengembangan fasilitas dan sumber belajar, guru disamping harus mampu membuat sendiri alat pembelajaran dan alat peraga, juga harus berinisiatif mendayagunakan lingkungan sekitar sekolah sebagai sumber belajar yang lebih konkret. Pendayagunaan lingkungan sebagai sumber belajar, misalnya memanfaatkan batu-batuan, tanah, tumbuh-tumbuhan, keadaan alam, pasar, kondisi sosial, ekonomi, dan budaya kehidupan yang berkembang di masyarakat.

Dalam kurikulum 2013 dinyatakan bahwa pembelajaran di sekolah menekankan pada aspek pengalaman belajar yang sesuai dengan minat dan bakat peserta didik. Melihat bahwa karakteristik peserta didik disetiap wilayah di Indonesia berbeda satu dengan yang lainnya, maka perlu dilakukan identifikasi unsur budaya lokal (kearifan lokal) dalam sumber belajar siswa. Untuk itu perlu dilakukan analisis terhadap kebutuhan unsur-unsur budaya lokal ini ke dalam bahan ajar yang digunakan dalam kegiatan pembelajaran. Sehingga unsur budaya lokal dapat diintegrasikan dengan bahan ajar. Sebagian besar siswa masih menggunakan bahan ajar cetak (Byars, 2015). Padahal dari segi biayanya bahan ajar cetak ini lebih mahal dibandingkan dengan bahan ajar elektronik. Hasil penelitian yang dilakukan oleh (Rockinson dkk, 2012) menunjukan bahwa siswa yang menggunakan buku elektronik memiliki tingkat pembelajaran afektif dan psikomotor yang lebih tinggi. Berdasarkan penelitian tersebut maka, bahan belajar yang akan dikembangkan pada penelitian adalah bahan ajar elektronik. Bahan ajar elektronik dapat mempermudah dalam memasukkan unsur suara dan gambar dinamis.

Buku elektronik adalah buku yang dipublikasikan dalam format digital, berisi tulisan, gambar, yang dapat dibaca melalui perangkat komputer atau perangkat digital lainnya. Buku ajar elektronik ini adalah buku yang didesain untuk membantu pembelajaran di kelas dan dapat menyimpan nilai dari kegiatan yang dilakukan oleh siswa (Anori dkk, 2013). Bahan ajar elektronik adalah seperangkat materi atau substansi pelajaran yang disusun secara runtut dan sistematis serta menampilkan sosok utuh dari kompetensi yang akan dikuasai siswa dalam kegiatan pembelajaran yang dikemas dalam interaktif multimedia (Abdillah, 2010).

Dasna dkk (2015) menyebutkan bahwa dalam konteks pembelajaran sering anda ketahui istilah pemanfaatan multimedia dalam pembelajaran. Multimedia berarti beberapa media yang tercakup dalam media itu seperti video, audio, gambar, animasi, dan grafis lainnya. Multimedia dapat membantu peserta didik memvisualkan sesuatu materi yang abstrak. Belajar dengan bantuan multimedia dapat memotivasi siswa dan menciptakan belajar aktif (Muller, Lee, \& Sharma, 2008). Maksud dari multimedia disini yaitu media yang dapat menyajikan unsur media secara lengkap seperti suara, animasi, video, grafis, dan film. Multimedia yang dimaksud juga sering diidentikan dengan komputer, internet, dan pembelajaran berbasis komputer (Abdillah, 2010).

Pembelajaran untuk meningkatkan apresiasi siswa terhadap budaya menekankan pembelajaran bermakna (Ibrahim dan Sukmadinata, 2010). Pembelajaran bermakna adalah pembelajaran yang melibatkan seluruh sensoris peserta didik. Keterlibatan ini tentunya harus mendapat dukungan strategi penyampaian materi dengan yang memaksimalkan fungsi panca indera (Mayer, 2007). Maksimalnya fungsi tersebut dapat dilakukan dengan menggunakan media pembelajaran yang mengandung teks, video dan animasi (multimedia). Penggunaan 
multimedia juga harus didukung oleh konten dan konteks kearifan lokal di mana peserta didik tersebut berasal (Laksana dan Widiastika, 2017).

Imam (2015) mengatakan bahwa seiring berkembangnya ilmu pengetahuan dan teknologi, membawa dampak di dalam dunia pendidikan, salah satunya adalah dirumuskannya Kurikulum 2013. Pada kurikulum tersebut guru diwajibkan untuk mengintegrasikan TIK ke dalam proses pembelajaran. Permendiknas Nomor 16 Tahun 2007 mengenai Standar Kualifikasi Akademik dan Kompetensi Guru terdapat empat kompetensi yang harus dikuasai oleh guru, dua diantaranya kompetensi pedagogik dan kompetensi profesional. Kompetensi pedagogik meliputi pemanfaatkan TIK untuk kepentingan pengelolaan pembelajaran, dan kompetensi profesional meliputi memanfaatkan TIK untuk berkomunikasi dan mengembangkan keprofesian berkelanjutan. Kedua kompetensi tersebut menjadi landasan pemanfaatan TIK dalam pembelajaran merupakan sesuatu yang sangat penting untuk menunjang keberhasilan dalam pencapaian tujuan pembelajaran. Pemanfaatan TIK dalam pembelajaran kurikulum 2013 meliputi, (1) Pemanfaatan teknologi informasi dan komunikasi dalam perencanaan pembelajaran, (2) Pemanfaatan teknologi informasi dan komunikasi dalam proses pembelajaran, (3) Pemanfaatan teknologi informasi dan komunikasi dalam evaluasi pembelajaran.

Namun pada prakteknya di lapangan, pembelajaran yang terjadi di Kabupaten Ngada banyak yang masih bersifat tradisional, apalagi pada sekolah-sekolah yang berada di daerah pinggiran. Sarana dan prasarana yang tersedia sangat minim. Selain itu, kegiatan pembelajaran belum memanfaatkan teknologi informasi sebagai media pengantar sebagaimana diisyaratkan dalam Kurikulum 2013. Siswa yang bersekolah rata-rata berasal dari keluarga menengah ke bawah. Sehingga guru hanya memanfaatkan buku sebagai media dalam pembelajaran (Laksana dkk, 2015).

Materi yang diajarkan pada kurikulum 2013 yaitu secara tematik. Pembelajaan tematik adalah pembelajaran terpadu yang menggunakan tema untuk mengaitkan beberapa mata pelajaran sehingga dapat memberikan pengalaman bermakna kepada siswa (Hakim, 2014). Keterpaduan berdasarkan tema ini menurut Hartono (2011) akan menghubungkan persoalan satu dengan persoalan lainnya, sehingga terbangunlah kesatuan (unity) pengetahuan. Sebuah pengetahuan yang mempresentasikan kesatuan bagian-bagian dengan keseluruhannya. Integrasi dalam pembelajaran diharapkan melahirkan pemahaman yang komprehensif pada diri peserta didik dan lingkungannya. Hal ini terkait dengan pemahaman bahwa diri manusia adalah bagian dunia yang lebih luas, sehingga peserta didik mampu memahami pengetahuan yang diterimanya melalui kurikulum beserta implementasi dan perkembangannya dalam kehidupan sehari-hari.

Dasna dkk (2015) mengatakan bahwa pembelajaran tematik lebih menekankan pada penerapan konsep belajar sambil melakukan sesuatu (learning by doing). Oleh sebab itu, guru perlu merancang pengalaman belajar yang akan mempengaruhi kebermaknaan belajar peserta didik. Pengalaman belajar yang menunjukan kaitan unsur-unsur konseptual menjadikan proses pembelajaran lebih efektif. Kaitan konseptual antar mata pelajaran yang dipelajari akan membentuk skema sehingga peserta didik akan memperoleh keutuhan pengetahuan. Selain itu, dengan penerapan pembelajaran tematik di Sekolah Dasar akan sangat membantu peserta didik, karena sesuai dengan tahap perkembangannya peserta didik yang masih melihat segala sesuatu sebagai satu keutuhan (holistik).

Salah satu karakteristik dari pembelajaran tematik menurut (Dasna dkk, 2015) adalah bersifat fleksibel artinya di mana guru dapat mengaitkan bahan ajar dari satu mata pelajaran dengan mata pelajaran yang lainnya, bahkan mengaitkannya dengan kehidupan nyata peserta didik dan keadaan lingkungan di mana sekolah dan peserta didik tersebut berada. Keadaan lingkungan yang dimaksud tersebut adalah salah satunya budaya lokal setempat.

Pembelajaran berbasis budaya lokal menjadi sebuah media bagi siswa untuk mentransformasikan hasil observasi mereka ke dalam bentuk prinsip-prinsip yang kreatif tentang alam. Dengan demikian, melalui pembelajaran berbasis budaya, siswa bukan sekedar meniru dan atau menerima saja informasi yang disampaikan, tetapi siswa menciptakan makna dan pemahaman dari informasi yang diperolehnya. Demikian juga, pembelajaran berbasis budaya bukan sekedar menstransfer atau menyampaikan budaya atau perwujudan budaya, tetapi menggunakan budaya untuk menjadikan siswa mampu menciptakan makna, menembus batas imajinasi, dan kreativitas untuk mencapai pemahaman yang mendalam tentang materi subyek yang dipelajarinya.

Unsur budaya lokal ini cocok dimasukan ke dalam bahan ajar siswa, khususnya siswa di Sekolah Dasar. Namun, bahan ajar yang sekarang digunakan disekolah-sekolah masih menggunakan bahan ajar cetak yang disediakan oleh pemerintah yang mungkin kurang mengedepankan unsur budaya lokal masyarakat setempat. Bahan ajar cetak ini juga kurang menarik dan membuat siswa mudah jenuh dalam membacanya. Guru perlu 
menyusun bahan ajar yang lebih menarik dan bersifat kontekstual. Bahan ajar yang cocok digunakan agar siswa tidak cepat bosan adalah bahan ajar elektronik, karena bahan ajar elektronik ini memuat unsur teks, gambar, audio dan video (multimedia). Berdasarkan uraian di atas, maka dilakukan penelitian pengembangan bahan ajar elektronik bermuatan multimedia pada tema peduli terhadap makhluk hidup untuk siswa Sekolah Dasar kelas IV di Kabupaten Ngada.

\section{Metode Penelitian}

Penelitian ini merupakan penelitian pengembangan. Bahan ajar elektronik ini dikembangkan dengan model ADDIE. Model ini terdiri atas lima langkah yaitu, (1) analyze, (2) design, (3) development, (4) implementation, dan (5) evaluation (Anglada, 2007). Pemilihan model ini didasari atas pertimbangan bahwa model ini dikembangkan secara sistematis dan berpijak pada landasan teoretis desain pembelajaran. Model ini disusun secara terprogram dengan urutan-urutan kegiatan yang sistematis dalam upaya pemecahan masalah belajar yang berkaitan dengan sumber belajar yang sesuai dengan kebutuhan dan karakteristik peserta didik.

Data yang telah dikumpulkan dalam penelitian ini dianalisis secara deskriptif kualitatif sebagai berikut, (1) Data mengenai kualitas bahan ajar elektronik bermuatan multimedia hasil review ahli dianalisis secara deskriptif untuk mengolah data hasil review ahli materi, ahli desain pembelajaran, ahli media pembelajaran dan uji coba siswa. Teknik analisis data ini dilakukan dengan mengelompokan informasi dari data kualitatif yang berupa masukan, tanggapan, kritik, dan saran perbaikan yang terdapat pada angket. Hasil analisis ini kemudian digunakan untuk merevisi produk yang dikembangkan, (2) Data mengenai kualitas bahan ajar elektronik bermuatan multimedia hasil uji coba produk dianalisis melalui konversi skor yang didapat dari lembar kuisoner. Pengubahan hasil penilaian dari guru dan siswa dari bentuk kualitatif ke bentuk kuantitatif skala 5. Produk yang dikembangkan dikatakan memiliki derajat validitas atau kualitas yang baik, jika minimal kriteria validitas yang dicapai adalah kriteria baik.

\section{Hasil Penelitian dan Pembahasan Hasil Penelitian}

\section{Tahap Analyze (Analisis)}

Pengembangan bahan ajar elektronik bermuatan multimedia ini, terlebih dahulu dilakukan analisis silabus kelas IV Tema "Peduli Terhadap Makhluk Hidup" yang mendeskripsikan konten dan konteks budaya lokal masayakat Ngada yang bisa diintegrasikan kedalam bahan ajar elektronik yang dikembangkan.

\section{Tahap Design (Desain)}

Hasil analisis pada tahap analisis dijadikan sebagai dasar dalam pengembangan bahan ajar elektronik. Bahan ajar yang dikembangkan adalah bahan ajar untuk siswa sekolah dasar kelas IV pada tema peduli terhadap makhluk hidup. Selain itu, buku tematik yang sudah ada atau yang disediakan oleh pemerintah juga dijadikan sebagai bahan referensi untuk mengembangkan bahan ajar yang baru. Hal-hal yang dilakukan dalam tahap desain ini adalah dengan menyusun draf bahan ajar pada program microsoft word 2007, kemudian mencari gambargambar yang berkaitan dengan materi untuk digunakan dalam bahan ajar yang dikembangkan. Selain itu, peneliti juga membuat video-video untuk dimasukan kedalam bahan ajar yang dikembangkan yang berkaitan dengan materi. Gambar maupun video yang diambil harus yang bersifat kontekstual atau yang berbasis budaya lokal.

\section{Tahap Development (Pengembangan)}

Pada tahap pengembangan ini, peneliti membahas tentang hasil pengembangan bahan ajar elektronik yang sudah direvisi oleh ahli. Hasil pengembangan bahan ajar elektronik bermuatan multimedia adalah sebagai berikut.

a. Cover

Cover merupakan tampilan dari buku elektronik yang dikembangkan, baik tampilan awal maupun tampilan akhir. Pada tampilan awal berisi gambar Sumber Daya Alam (SDA) dan diisi tulisan "Buku Tematik Elektronik, Berdasarkan Kurikulum 2013, untuk SD kelas IV, Tema 3 Peduli Terhadap Makhluk Hidup” sedangkan pada tampilan akhir berisi tulisan "Buku Tematik Elektronik, Berdasarkan Kurikulum 2013, untuk SD kelas IV”. Gambar tampilan cover buku elektronik yang dikembangkan dapat dilihat pada gambar berikut ini. 


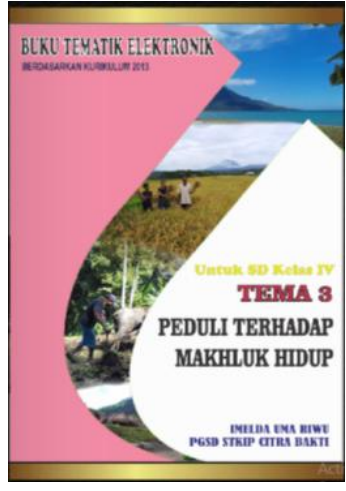

Gambar 1. Cover Depan

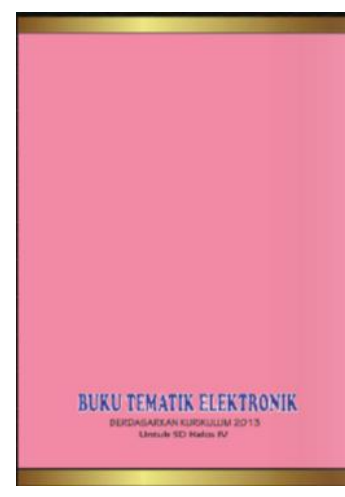

Gambar 2. Cover Belakang

b. Panduan Penggunaan Bahan Ajar

Panduan penggunaan bahan ajar elektronik ini dirancang sangat sederhana dan bertujuan untuk menyampaikan kepada siswa tentang isi dari bahan ajar yang akan mereka pelajari dan terdapat penjelasan mengenai petunjuk penggunaan bahan ajar elektronik bermuatan multimedia ini.

c. Daftar Isi

Bahan ajar elektronik yang dikembangkan juga terdapat daftar isi yang memudahkan pembaca atau pengguna produk menentukan sub tema mana dan halaman berapa yang akan mereka pelajari dan dibuat dengan tampilan warna huruf yang menarik.

d. Jaringan Tema

Tema yang dikembangkan adalah tema 3 "Peduli Terhadap Makhluk Hidup" siswa sekolah dasar kelas IV. Jaringan tema yang terdapat pada bahan ajar elektronik ini berisi tentang beberapa mata pelajaran (Bahasa Indonesia, Matematika, PPKn, IPA, IPS, SBdP, dan PJOK) dan dilengkapi dengan Kompetensi Dasar serta Indikator Pembelajaran yang akan dicapai siswa dalam tema tersebut. Jaringan tema dibuat dan dirancang sedemikian rupa dan terlihat menarik.

e. Sub Tema

Pada e-book ini dirancang 3 subtema yaitu "Hewan dan Tumbuhan di Lingkungan Rumahku", "Keberagaman Makhluk Hidup di Lingkunganku”, dan "Ayo Cinta Lingkungan”. Masing-masing subtema terdiri dari 6 pembelajaran yang mencakup pengetahuan, keterampilan dan sikap.

\section{Tahap Evaluation (Evaluasi)}

Tahap evaluasi merupakan tahap yang dilakukan untuk merevisi setiap tahap-tahap pengembangan lainnya. Hasil evaluasi setiap tahap adalah sebagai berikut. Revisi tahap analisis, yang dilakukan adalah analisis silabus kelas IV tema peduli terhadap makhluk hidup yang mendeskripsikan konten dan konteks kearifan lokal masyarakat Ngada yang dapat diintergrasikan ke dalam bahan ajar yang dikembangkan. Setelah melakukan analisis silabus kemudian peneliti melakukan revisi berdasarkan komentar yang diberikan oleh dosen pembimbing. Hasil revisi pada tahap analisis ini adalah pada kolom tabel analisis ditambahkan dengan sumber belajar yang berisi tentang konteks budaya lokal yang terdapat pada hasil analisis tersebut diperoleh dari mana dan berupa apa.

Revisi tahap design, peneliti membuat draf bahan ajar berdasarkan hasil analisis. Hasil revisi pada tahap design berdasarkan komentar dari dosen pembimbing adalah media-media yang terdapat dalam bahan ajar yang dikembangkan harus bersifat kontekstual yang dapat mendukung siswa terhadap pemahaman materi. Selain itu, tata letak pada draf bahan ajar juga diperbaiki, ukuran huruf, warna huruf dibuat lebih menarik lagi, template, panduan penggunaan bahan ajar, dan jaringan tema serta design cover baik cover depan maupun cover belakang.

Revisi tahap development atau pengembangan, peneliti mengkonversi bahan ajar yang dibuat dari program microsoft word 2007 ke dalam bentuk pdf kemudian dimasukan ke dalam aplikasi flip book maker. Hasil revisi pada tahan pengembangan berdasarkan komentar dosen pembimbing adalah perbaikan pada kualitas video, tata letak tabel, gambar, bagan, dan video.

Revisi tahap implementasi, peneliti membahas tentang hasil revisi produk bahan ajar elektronik berdasarkan komentar maupun saran yang diberikan oleh masing-masing validator pada saat uji coba. Revisi produk pada tahap evaluasi ini dilakukan agar menghasilkan produk yang layak. Berikut adalah hasil revisi produk (bahan ajar elektronik) berdasarkan komentar maupun saran dari masing-masing validator. 
Revisi Produk oleh Ahli Konten/Isi. Penilaian yang diberikan oleh ahli konten/isi terhadap produk bahan ajar elektronik yang dikembangkan ada pada kategori sangat baik. Penilaian oleh ahli konten ini juga tidak terdapat saran maupun komentar yang diberikan untuk direvisi atau diperbaiki. Sehingga bahan ajar elektronik ini dinyatakan layak untuk diujicobakan tanpa revisi.

Revisi Produk oleh Ahli Desain Pembelajaran. Penilaian yang diberikan oleh ahli desain pembelajaran terhadap bahan ajar elektronik yang dikembangkan ada pada kategori sangat baik. Adapun saran maupun komentar yang diberikan untuk bahan revisi terhadap produk yang dikembangkan yaitu pada tata letak tabel yang terdapat pada bahan ajar elektronik tersebut diatur lebih rapi lagi.

Revisi Produk oleh Ahli Multimedia. Penilaian oleh ahli multimedia terhadap bahan ajar elektronik yang dikembangkan ada pada kategori baik. Saran perbaikan yang diberikan oleh ahli multimedia terdapat pada aspek cover pada indikator pusat pandang, aspek tipografi pada pengaturan jarak, aspek tampilan pada konsistensi layout tata letak dan pemilihan background, aspek video pada kualitas video dan volume suara, yang terakhir aspek pengoperasian pada kemudahan penggunaan bahan ajar elektronik. Perbaikan untuk setiap aspek tersebut sudah dilakukan, tetapi ada aspek-aspek tertentu yang tidak dapat diperbaiki dikarenakan bahan ajar elektronik yang dikembangkan menggunakan program flip book maker ini tentu memiliki kelebihan maupun kekurangan. Sedangkan yang dimaksud oleh ahli multimedia ini adalah media-media yang terdapat pada bahan ajar yang dikembangkan harus lebih interaktif lagi dan memperhatikan prinsip-prinsip yang berlaku pada multimedia serta menggunakan kemampuan komputer secara optimal. Tujuan awal peneliti dalam mengembangkan bahan ajar elektronik ini adalah menggunakan program atau aplikasi flip book maker. Alasan peneliti mengembangkan produk menggunakan aplikasi flip book maker ini, karena aplikasi ini sangat sederhana dan lebih mudah dalam pembuatannya. Revisi yang dilakukan oleh peneliti berdasarkan saran yang diberikan oleh ahli multimedia adalah pada aspek pemilihan background, warna pada latar sebaiknya menjaga kontras.

Revisi Produk oleh Siswa Sebagai Pengguna Produk. Penilaian bahan ajar elektronik berdasarkan hasil uji coba siswa sebagai pengguna produk ada pada kategori sangat baik. Uji coba dilakukan dengan melibatkan 5 (lima) orang siswa Sekolah Dasar kelas IV. Pada umumnya komentar maupun saran yang diberikan oleh masingmasing siswa menunjukan bahwa bahan ajar elektronik yang dikembangkan sangat menarik dan mendukung siswa terhadap pemahaman materi. Saran perbaikan terhadap bahan ajar yang dikembangkan terletak pada ukuran huruf. Ukuran huruf yang diminta agar sebisa mungkin diperbesar lagi dan diberi warna agar terlihat menarik. Ukuran huruf sudah diperbesar dengan ukuran 18 dan menggunakan jenis huruf century gothic.

Selain itu kecintaan para generasi pembelajar di Ngada terhadap budaya juga dapat mendukung penerapan pembelajaran berbasis budaya lokal. Hal ini ditunjukkan dalam sebuah riset yang dilakukan oleh Qondias dan Dopo (2015) berjudul "Pemetaan Tingkat Kecintaan Generasi Muda Suku Ngada pada Pesta Adat Reba di Era Globalisasi". Hasil penelitian menunjukkan bahwa para generasi muda di beberapa wilayah di Ngada sangat cinta terhadap budayanya terutama pesta adat reba. Oleh karena itu, pendidikan berbasis budaya dalam pembelajaran sangat bermanfaat bagi pemaknaan awal proses dan hasil belajar, karena peserta didik mendapatkan pengalaman belajar yang kontekstual dan bahan apersepsi untuk memahami konsep ilmu pengetahuan dalam budaya lokal yang dimiliki (Tanu, 2017).

\section{Pembahasan}

Pengembangan bahan ajar elektronik bermuatan multimedia ini tersusun dalam enam bagian utama yaitu : 1) Panduan penggunaan bahan ajar, 2) Jaringan tema, 3) Apa saja yang dipelajari pada tiap sub tema, 4) Pemetaan indikator pembelajaran, 5) Kegiatan pembelajaran, 6) Latihan soal. Berikut adalah penjelasan untuk masing-masing bagian yang terdapat dalam bahan ajar elektronik yang telah dikembangkan :

1) Panduan penggunaan bahan ajar

Panduan penggunaan bahan ajar, menjelaskan kepada siswa agar siswa mendapat gambaran yang jelas dan rinci mengenai proses pembelajaran berbasis konten dan konteks budaya lokal masyarakat Ngada serta isi dari bahan ajar yang akan mereka pelajari tersebut. Selain itu, juga dijelaskan cara menggunakan bahan ajar elektronik yang sudah dikembangkan tersebut.

2) Jaringan tema

Jaringan tema yang terdapat pada bahan ajar elektronik ini berisi tentang beberapa mata pelajaran (Bahasa Indonesia, Matematika, PPKn, IPA, IPS, SBdP, dan PJOK) yang dilengkapi dengan kompetensi dasar serta indikator pembelajaran yang akan dicapai siswa dalam tema tersebut. 
3) Apa saja yang dipelajari pada tiap sub tema

Pada setiap sub tema yang dibuat ini berisi tentang kegiatan pembelajaran dan kompetensi yang dikembangkan berupa pengetahuan, keterampilan dan sikap pada setiap pembelajaran.

4) Pemetaan indikator pembelajaran

Pemetaan indikator pembelajaran, menampilkan peta indikator untuk semua materi yang menjadi fokus dalam setiap pembelajaran. Peta indikator ini dapat menghubungkan dan mempermudah alur pikir guru dalam menyajikan dan mengelola pembelajaran serta siswa dapat mengikuti pola tersebut dengan terintegrasi berdasarkan tema yang diangkat.

5) Kegiatan pembelajaran

Kegiatan pembelajaran terdiri dari berbagai aktivitas. Aktivitas yang dimaksud adalah aktivitas untuk melatih keterampilan dalam melakukan atau menghasilkan sesuatu. Misalnya aktivitas "ayo berkarya" dan "ayo berlatih". Aktivitas lainnya adalah "ayo membaca", "ayo berdiskusi", "ayo mengamati", aktivitas ini muncul dihampir setiap kegiatan pembelajaran. Kegiatan-kegiatan ini bertujuan untuk mendorong kemampuan berpikir dan kemampuan dalam memecahkan masalah.

6) Latihan soal

Latihan soal ini terintegrasi disetiap aktivitas pembelajaran. Jadi tidak disusun terpisah dengan materi pembelajaran. Hal ini dilakukan dengan pertimbangan, pembelajaran tematik ini menggabungkan berbagai tujuan pembelajaran, sehingga setiap aktivitas pembelajaran selalu disertai dengan latihan soal.

Bahan ajar elektronik bermuatan multimedia yang dikembangkan dalam penelitian ini, sudah sesuai dengan definisi yang diberikan oleh ahli dan pemerintah. Bahan ajar adalah seperangkat materi yang disusun secara sistematis baik tertulis maupun tidak tertulis sehingga tercipta lingkungan atau suasana yang memungkinkan siswa belajar (Kemendikbud, 2013). Selain itu, Dirjen Dikti (2014) juga menambahkan bahwa buku ajar merupakan informasi, alat atau teks yang diperlukan guru atau instruktur untuk perencanaan dan penelaahan implementasi pembelajaran.

Berdasarkan respon siswa terhadap bahan ajar elektronik yang dikembangkan ini dapat meningkatkan motivasi belajar. Hal ini dibuktikan dengan penelitian yang dilakukan oleh (Wiyoko dkk, 2014), bahwa pengembangan modul elektronik animasi interaktif dapat meningkatkan motivasi belajar siswa. Penelitian lain yang dilakukan oleh (Rahmatia dkk, 2017) yang mengatakan bahwa media pembelajaran elektronik berpengaruh baik terhadap hasil belajar matematika siswa Sekolah Dasar pada materi pecahan di kelas IV. Bahan ajar elektronik bermuatan multimedia ini juga sangat simpel dan mudah dibawa kemana-mana. Hal ini dibuktikan dengan penelitian yang dilakukan oleh (Handayani, 2016) yang menyatakan bahwa bahan ajar berbasis mobile Learning dapat disajikan dengan menggunakan media elektronik seperti laptop, ponsel, dan tablet sehingga lebih mudah dibawa dan dipelajari kapanpun dan dimanapun.

Hasil uji coba bahan ajar elektronik oleh siswa sebagai pengguna produk ada pada kategori sangat baik. Aspek tertinggi ada pada video mendukung pemahaman materi. Bahan ajar elektronik bermuatan multimedia (teks, gambar, dan video) ini dapat mendukung pemahaman siswa terhadap materi yang mereka pelajari. Bedasarkan temuan yang dilakukan oleh (Oka dkk, 2017), bahwa bahan ajar interaktif (teks, audio, gambar dan video) mampu meningkatkan hasil belajar mahasiswa untuk matakuliah multimedia.

Dalam pengembangan bahan ajar, digunakan bahan ajar elektronik untuk mempermudah siswa dalam mempelajari materi karena materi yang terdapat di dalam bahan ajar elektronik ini adalah materi yang berbasis budaya lokal artinya bahan ajar tersebut bersifat kontekstual. Penyajian bahan ajar dalam bentuk elektronik ini memberikan banyak kemudahan serta lebih menarik (Abdillah, 2010). Pengembangan aktivitas pembelajaran berbasis nilai budaya lokal memberikan kontribusi positif untuk meningkatkan literasi siswa berbasis kompetensi (Wahyudin, 2015). Pengembangan multimedia pembelajaran tematik Sekolah Dasar berbasis budaya lokal masyarakat flores berdasarkan hasil uji coba ada pada kategori sangat baik (Laksana dan Widiastika, 2017). Integrasi nilai budaya lokal dalam pengembangan kurikulum seperti membuat tujuan belajar, merancang bahan belajar, menentukan strategi pembelajaran, media belajar, dan evaluasi pembelajaran adalah penting dilakukan untuk kualitas pembelajaran (Northcote, dkk., 2014).

Duncan (2014) dalam penelitiannya juga mengungkapkan bahwa pengalaman awal menjadi dasar dalam melaksanakan pembelajaran. Guru dengan budaya yang berbeda dengan siswa, lebih sulit dalam memberikan pengalaman belajar yang sesuai dengan konteks budaya. Temuan lain juga diuangkapkan oleh Laksana dan Wawe (2015), bahwa pembelajaran IPA dengan bantuan media terutama media berbasis budaya 
lokal memperlihatkan hasil yang memuaskan. Aktivitas belajar meningkat yang disertai dengan penguatan pemahaman konsep IPA siswa. Dengan demikian kajian budaya lokal harus terintegrasi dalam bahan pembelajaran sebagai upaya dalam meningkatkan kualitas pembelajaran

\section{Simpulan}

Dari pemaparan yang dilakukan sebelumnya, adapun kesimpulan dari penelitian ini adalah hasil pengembangan bahan ajar elektronik bermuatan multimedia terdiri dari beberapa bagian diantaranya cover, panduan penggunaan bahan ajar, daftar isi, jaringan tema, sub tema 1 (pembelajaran 1-6), sub tema 2 (pembelajaran 1-6), sub tema 3 (pembelajaran 1-6), latihan soal dan yang terakhir adalah daftar pustaka. Bahan ajar elektronik bermuatan multimedia ini kemudian dilakukan uji coba kepada ahli konten, ahli desain pembelajaran, ahli multimedia dan siswa sebagai pengguna produk. Hasil uji coba diperoleh dengan cara penilaian melalui lembar kuisioner, dapat dikategorikan bahwa kualitas bahan ajar elektorik pada kelayakan isi berdasarkan uji coba ahli konten ada pada kategori "Sangat Baik", kualitas bahan ajar elektronik berdasarkan uji coba ahli desain pembelajaran ada pada kategori "Sangat Baik", kualitas bahan ajar elektronik hasil uji coba ahli multimedia ada pada kategori "Baik", dan kualitas bahan ajar elektronik hasil uji coba pengguna produk (siswa) ada pada kategori "Sangat Baik". Dengan demikian, berdasarkan hasil uji coba bahan ajar elektronik oleh ahli dan siswa sebagai pengguna produk dinyatakan layak untuk digunakan dalam proses pembelajaran.

\section{Daftar Pustaka}

Abdillah, A.N. 2010. Konsep Bahan Ajar Elektronik dan Ciri/Karakteristik Bahan Ajar Elektronik. (Online) melalui https://sites.google.com>elearningtp2010, diakses 14 Februari 2018

Anglada, D. 2007. An Introduction to Instructional Design: Utilizing a Basic Design Model. (Online) melalui http://www.pace.sdu/ctlt/newsletter, diakses 14 februari 2018.

Anori, S., Putra, A. dan Asrizal. 2013. Pengaruh Penggunaan Buku Ajar Elektronik dalam Model Pembelajaran Langsung Terhadap Hasil Belajar Siswa Kelas X SMAN 1 Lubuk Alun. Padang : Pilar Of Physics Education, Vol. 1.April 2013, 104-111

Byars, M.N. 2015. Printed Books versus Digital Books. California: the Faculty of the Graphic Communication Departement California Polytechnic State University

Dasna, I.W, Laksana D.N.L, dan Sudatha I.G.W. 2015. Desain dan Model Pembelajaran Inovatif dan Interaktif. Tangerang Selatan: Universitas Terbuka

Depdiknas. 2003. Pendekatan Kontextual (CTL). Jakarta: Depertemen Pendidikan Nasional.

Dirjen Dikti (Direktorat Jenderal Pendidikan Tinggi). 2014. Pedoman operasional penilaian angka kredit kenaikan pangkat/jabatan akademik dosen. Jakarta: Kemendikbud.

Duncan, M. (2014). How the Cultural Contexts of Urban Teaching Affect Novice Science Educators: Implications for School Leaders. International Journal of Educational Leadership Preparation, 9 (1), 1-17

Hakim, I.N. 2014. Pembelajaran Tematik-Integratif di SD/MI dalam Kurikulum 2013. Insania, Vol. 19, No. 1. 2014

Handayani, R.D. 2016. Pengembangan Bahan Ajar Elektronik Berbasis Mobile Learning pada Mata Kuliah Optik di FKIP Universitas Jember. Jurnal Ta'dib. Vol. 17, No. 1, 81-85

Hartono. 2011. Pendidikan Integratif. Purwokerto: STAIN Press.

Ibrahim, A. dan Sukmadinata, N.S. 2010. Pengembangan Model Pembelajaran Terpadu Berbasis Budaya untuk Meningkatkan Apresiasi Siswa Terhadap Budaya Lokal. Cakrawala Pendidikan, Th.XXIX, No.2

Kemendikbud. 2013. Penyusunan rencana pelaksanaan pembelajaran. Jakarta: Kepala Badan Pengembangan Sumber Daya Manusia Pendidikan dan Kebudayaan dan Penjaminan Mutu Pendidikan.

Kemendikbud. 2013. Permendikbud : Standar Kompetensi Lulusan Pendidikan Dasar dan Menengah. Jakarta : Kementerian Pendidikan dan Kebudayaan.

Laksana, D.N L. \& Wawe, F. (2015). Penggunaan Media Berbasis Budaya Lokal Dalam Pembelajaran IPA untuk Meningkatkan Aktivitas dan Pemahaman Konsep IPA Siswa Sekolah Dasar. Jurnal Ilmiah Pendidikan Citra Bakti, 2 (1), 27-37. 
Laksana, D.N.L dan Riwu, I.U. 2018. Inovasi Aktivitas Belajar dalam Menanamkan Nilai Karakter di Sekolah Dasar yang Menerapkan Program Full Day School. Jurnal Ilmiah Pendidikan Citra Bakti. 188-194

Laksana, D.N.L dan Widiastika, I.G. 2017. Pengembangan Multimedia Pembelajaran Tematik Sekolah Dasar Berbasis Budaya Lokal Masyarakat Flores. Jurnal Pendidikan Dasar Nusantara, Vol. 2 no. 2 (2017).

Laksana, D.N.L., Kurniawan, P.A.W., dan Niftalia, I. 2016. Pengembangan Bahan Ajar Tematik SD Kelas IV Berbasis Kearifan Lokal Masyarakat Ngada. Jurnal Ilmiah Pendidikan Citra Bakti, Vol. 3, No.1 (2016)

Mayer, R. E. (2007). Multimedia Learning. New York: Cambridge University Press

Mulyasa, H.E. 2015. Pengembangan dan Implementasi Kurikulum 2013. Bandung: PT. Remaja Rosdakarya

Northcote, M., Kilgour, P., Reynaud, D., \& Fitzsimmons, P. (2014). Engaging in Deep Cultural Learning through the Intersection of Multiple Contexts. Australian Journal of Teacher Education. 39 (10), 47-63

Oka, G.P.A. 2017. Pengembangan Bahan Ajar Interaktif Berbasis Component Display Theori (CDT) Pada Mata Kuliah Multimedia Jurusan Teknologi Pendidikan FIP Undiksha. Jurnal Imedtech. Vol. 1, No. 1

Rahmatia, M., Monawati., dan Darnius, S. 2017. Pengaruh Media E-Learning Terhadap Hasil Belajar Matematika Siswa Kelas IV SDN 20 Banda Aceh. Jurnal Ilmiah Pendidikan Guru Sekolah Dasar. Vol. 2, No. 1, 212227

Rockinson, A.J., Courduff, J., Carter, K. dan Bennett, D. 2013. Electronic versus Traditional Print Textbooks: A Comparison Study on the Influence of University Students Learning. Jour nal Hompage, 63 (2013) 259266

Wahyudin, U. (2015). The Quality of a „Local Values Based ${ }^{e e}$ Fuctional Literacy Program: Its Contribution to the Improvement of the Learner"es Basic Competencies. International Education Studies, 8 (2), 121-127

Wiyoko, T., Sarwanto., dan Rahardjo, D.T. 2014. Pengembangan Media Pembelajaran Fisika Modul Elektronik Animasi Interaktif Untuk Kelas XI SMA Ditinjau Dari Motivasi Belajar Siswa. Jurnal Pendidikan Fisika. Vol. 2, No. 2, 11. 